Marmara Üniversitesi Siyasal Bilimler Dergisi • Marmara University Journal of Political Science, Cilt 9, Özel Sayı, Kasım 202I, ISSN 2147-6926, ss. e22-e44• DOI: 10.14782/marmarasbd.913427

ARAŞTIRMA MAKALESI / RESEARCH ARTICLE

\title{
Kapitalist Devletler Ekolojik Krizle Neden Covid-19'la Olduğu Gibi Savaşmazlar? Pandemiye Politik Ekolojik Bir Yaklaşım
}

\author{
Why Don't the Pandemic-Fighting Capitalist States Fight Ecological \\ Crisis in the Same Way? A Political-Ecological Approach to the \\ Pandemic
}

\section{Aybala ERTEKIN ${ }^{*}$}

\begin{abstract}
Öz
Covid-19 virüsüyle mücadele tecrübesi, devletlerin ekolojik krize karşı savunmasız olduğunu göstermiştir. Bir seneyi aşkın süredir kontrol altına alınamayan bu salgın karşısında kapitalist devletler önlem alabilmek için geleneksel eylem repertuvarının dışına taşan bazı politikalar üretmiştir. Öte yandan kapitalist devletlerin, ekolojik kriz bağlamında değerlendirilmesi gereken Covid-19 pandemisine karşı gösterdiği tepkiyi ekolojik kriz ile ilişkilendirilen diğer gündemlerde göstermediği tespit edilebilmektedir. Karmaşık bir ilişkiler ağı ortaya koyan kapitalizm, devlet, insan ve doğa ekolojik bir perspektifle ele alındığında, pandemi ve ekolojik kriz karşısında devletlerin tercihlerinin niteliği ve nedeni dikkat çekici olmaktadır. Çalışma bu sorunu irdelemek adına politik ekoloji perspektifinden hareketle üç hipotez sunmaktadır: Birincisi, koronavirüs pandemisi bir sağlık krizi olmanın yanı sıra ekolojik krizdir, bu iki krizi ayrıştırmak politik bir tercihtir. İkincisi, kendi başına pandemi gündemi devletlere kendi otoritelerini konsolide etmek anlamında ekolojik krizden farklı olarak bir politik araçsallaştırma imkânı sunmaktadır. Üçüncüsü, Covid-19'un yayılımını engelleyip kontrol altına alma yönündeki politika değişiklikleri, çeşitli sınıfsal ittifaklar aracılı̆̆ıyla kapitalist sistem ve devletin devamlılığını sağlıyorken, ekolojik kriz ile eşitlikçi bir mücadele kapitalist sisteme meydan okumayı dayatmaktadır.
\end{abstract}

Anahtar Kelimeler: Covid-19, pandemi, ekolojik kriz, kapitalizm, kapitalist devlet

\section{Abstract}

The apparent lack of effectiveness in contemporary states' fight against coronavirus show their unpreparedness to the impending ecological crisis. The states failed to set up containment mechanisms against the rapid dissemination of coronavirus and were unable to prevent the virus' mortal impacts for more than a year. Somehow, capitalist states implement certain policies to struggle against coronavirus thereby extending their ordinary limits of capitalist logic during the process. It has been demonstrated that the capitalist states do not act against ecological crises in the same way that they fight against coronavirus. Under the conditions of ecological crises, providing that capitalism, state, human, and nature build an intricate interrelationship; characteristics and reasons became a remarkable issue. Thus,

* Galatasaray Üniversitesi, E-posta: aybalaertekin@gmail.com, Orcid: 0000-0001-9822-7307 
this article puts forward three arguments in order to come up with possible answers to this question. First, the coronavirus crisis is not only a health crisis, but also an ecological one and it is a states' political choice to separate these two crises. Secondly, the health crisis concept led states to consolidate their political capacities through discourses used as a political instrument. Finally, when the political choice of the state is to control Coronavirus, it contributes to the state's and capitalist system's persistence by favouring social class alliances. But solving ecological problems poses a greater challenge to capitalism. Keywords: COVID-19, Pandemic, ecological crises, capitalism, capitalist state

$$
\begin{array}{r}
\text { "Doğru: hâlâ yaşayacak kadar kazanırım } \\
\text { Lâkin talihimdendir: inanın bana. } \\
\text { Yaptı̆̆ım hiçbir şey } \\
\text { Doyma hakkı vermiyor bana } \\
\text { Korunmuşluğum şans eseri (ki tükenirse } \\
\text { vay halime!)"1 }
\end{array}
$$

Aralık 2019'da Çin'de yayılmaya başlayıp yerküreyi kısa sürede etkisi altına alan, zoonotik bir hastalık türü olan Covid-19 virüsü bütün dünyanın mücadele ettiği bir pandemi halini almıştır. Kapitalist devletleri, neoliberalizme ters düşen kamusal politika üretme yoluyla bir süre olağan politik eylem repertuvarları dişında hareket etmeye iten bu deneyim, virüse karşı savaş söylemi geliştirilen bir süreci de beraberinde getirmiştir. Bugünün kapitalist devleti, Covid-19 düşmanı karşısında mücadele ederken sosyal hakları anımsamak zorunda kalan ve geniş kitlelere yönelik kararlar alabilen bir siyasal aygıt olarak karşımızda durmaktadır.

Kapitalist devletlerin, sağlık krizi formunda baş etmeye çalıştığı pandemiyi, kronik sorun olan ekolojik krizle ilişkili biçiminde ele almak, virüsün kapitalist sistem ile bağlantısını ortaya koyabilmek adına önem taşımaktadır. Bu bağlantı devletlerin iki kriz karşısındaki eylem tercihleriyle ilişkilendirilebilmektedir. İnsanlar ve hayvanların birbirleriyle temasından doğan hastalıklardan biri olarak Covid-19'un yabani hayvan ticaretinin en kalabalık ve küresel ölçekte gerçekleştirildiği bir bölgede ortaya çıkması dikkate değerdir. Çünkü bu durum, tüketim ve üretim faaliyetlerini ekonomi ve siyasalın ilişkiselliği içinde sorgulamak için somut bir deneyim alanı yaratmaktadır. Pandeminin etkilerini kontrol altına almak adına kapitalist devletlerin bu süreçte ekolojik kriz karşısındaki politik uygulamalarına nazaran daha hızlı ve radikal kararlar aldığı görülmektedir. Ekolojik kriz ile ilişkili olarak ele alınabilecek koronavirüs ile mücadelede stratejik bir tercih olarak savaş söylemi takip edilmektedir. Buna karşın devletlerin, günlük hayata sürekli temas etmeyen, yer yer doğal felaket görünümünde algılanan; fakat epidemi, türlerin yok olması, buzulların erimesi gibi kapitalizmin işleyiş dinamikleriyle bağlantılı olgularla varlığını duyuran ekolojik krizle pandemide olduğu biçimiyle mücadele etmedikleri görülmektedir. $\mathrm{Bu}$ sebeple, ekolojik kriz ve pandemi karşısında ayrıştırıcı düzeyde farklı tavır takınan devletlerin ideolojik tercihlerinin bir sonucu olduğu pandemi ile belirginleşen bu taktiksel tutumlarının sebepleri ve kapitalist sistem ile ilişkisi tartışma konusu hâline gelmektedir.

1 İngilizcesi, "It is true: I still earn a living / But believe me: that is just good fortune. Nothing / That I do gives me the right to eat my fill. / By chance I am spared. (If my luck runs out / I am lost.)" olan bir Brecht bercestesi. Bkz. (Kuhn ve Constantine, 2018). 
Buradan hareketle çalışma, Covid-19 pandemisine politik ekolojik bir yaklaşım geliştirme hedefinden yola çıkmaktadır. Ekolojik krizle mücadelede pandemiyle aynı ölçekte eylemeyen devletlerin Covid-19 ile neden savaştığı sorusuna yanıt verebilmek adına birbirine eklemlenen üç aşamalı bir tartışma yürütmek amaçlanmaktadır. Çalışmada ilk olarak Covid-19, doğanın metalaştırılması üzerinden ekolojik krizle ilişkili olarak ortaya konacaktır. Bu yolla pandemiyi ekolojik kriz olarak ele almak ile sağlık krizi biçiminde düşünmenin devletlerin politik tercihinin bir yansıması olduğu ileri sürülecektir. Kapitalist devlet ile doğa ilişkisinin politik ekolojik alandaki yerini konumlandırabilmek amacıyla teorik bir yapı olarak, Jason W. Moore’un dünyaekolojisi [world-ecology] yaklaşımı ve Sermaye Çağı [Capitalocene] kuramına başvurulacaktır. Ardından, Covid-19 ile ekolojik krizin birbirine bağlanan noktaları üzerinden kapitalist devletlerin ayrıştırılamayacak olan bu iki olgu karşısındaki eylemlerine yönelik bilinçli tercihleri gerekçelendirilmeye çalışllacaktır. Nihayetinde ise dünyanın yüzleştiği bu epidemik savaşın kapitalist devletlerce çeşitli söylemler vasıtasıyla araçsallaştırılmaya müsait olması ve bu yolla kriz zamanında toplumsal sınıf çelişkilerini örtebilme potansiyeli üzerinde durulacaktır.

\section{Covid-19 ve Ekolojik Kriz İlişkisi}

İnsan ile doğa arasında bedensel bir ilişki vardır; doğa, insanın yaşayabilmesi için sürdürmesi gereken bedenidir; bu, insanın doğa ile bağlantılı olduğu değil, insanın doğanın bir parçası olduğu anlamına gelir (Marx, 2015, s.145). Doğanın bileşenlerinden insan ve hayvanların etkileşimi tarımsal üretim, hayvansal tüketim, hayvan ticareti gibi çeşitli ekonomik faaliyet alanları doğurmaktadır. Bu bileşkelerin hesap edilmemiş sonucu olarak gündeme gelen Covid-19 virüsü ise bu etkileşimi ortaya koyan, zoonotik hastalıklar kategorisinde yer almaktadır (FAO, 2020). Daha çok vahşi hayvanlarla temastan kaynaklı enfekte olma durumu şeklinde tanımlanan, zoonotik hastalık ya da zoonos, temelde hayvanlardan insanlara geçen enfeksiyon ve hastalıklar bütünü olarak karşımıza çıkmaktadır (Bennett, 1999, s.514). Kaynağı kesin olarak tespit edilememekle birlikte, Wuhan'daki vahşi hayvan pazarından yayılmaya başlandığı öne sürülen Covid-19 virüsünün (Readfearn, 2020), ticaretin odak noktalarından birinde ortaya çıkması rastlantısal değildir. Egzotik gıda sektörünün anakarası bu ticaret merkezi sermayeye kaynak oluşturan, endüstriyel üretimin teşvik edildiği büyük bir pazar alanıdır (R. Wallace, Liebman, Chaves, ve Wallace, 2020). Vahşi hayvanların ticaretine kadar genişlemiş piyasaya mekân olan bu pazar alanından yayılarak Covid-19 adıyla açığa çıkan durum ise doğanın metalaştırılma kapasitesinin sınırları olduğu gerçeğidir. Sınıra dayanmış bir ekonomik sistemin politik örgütlenmesi olarak devletlerin yüzleştiği pandemiyle, mücadelede pandemide olduğu kadar ön plana çıkmadıkları ekolojik kriz ilişkisi bu bağlamda dikkat çekicidir.

Kapitalizmin dinamikleriyle ilişkilendirilebilecek olan pandeminin devletlerce ekolojik krizden ayrıştırılarak ele alınmasına politik ekolojik perspektiften bakabilmek için öncelikle zoonotik hastalıkların ekolojideki yerine değinmek, bununla birlikte ekolojik olanın ne olduğunu tespit etmek yerinde olacaktır. Pandemiyi insan-doğa ilişkisinde insanın doğaya hakim olduğu düşüncesiyle okumanın dışında, insanı doğanın bir parçası olarak (yeniden) kavrayan bir 
perspektifle ele almak mümkündür. Covid-19 virüsü ile ekolojik sistem, halk sağlığı ve kapitalist devlet arasındaki ilişkiyi kurabilmek için kapitalist çağı imleyen Kapitalosen ve dünya-ekolojisi terimleri elverişli birer çerçeve olarak karşımıza çımaktadır.

Kapitalosen / Sermaye Çağı olarak adlandırılan kuram öncelikle doğa-insan diyalektiğini olumlayan, doğa ve insanı bütüncül olarak gören yaklaşımdan hareket etmektedir (Moore, 2015, s. 173-195, 2016a, s.1-11). Moore kapitalizmi üretim/yeniden üretim ve güç ilişkileri tarihi olarak kavramsallaştırmakta (Moore, 2016c, s.81), kapitalist sistemin ortaya çıkardığ ilişkiler Moore’un teoreminin önemli bir parçasını oluşturmaktadır. Bir çağ olarak Kapitalosen vurgusu yapmak kapitalizmi ekonomik sistem oluşunun yanı sıra doğayı ve diğer ilişkileri düzenlemenin yolu olarak görmenin de bir başlangıcını oluşturmaktadır (Patel ve Moore, 2017). Bu sebeple yaklaşım, insan-doğa ilişkisine insan merkezli bakışın getirdiği olumsuz açıyı olumlu bir gözle yeniden yapılandırırken kapitalizm üzerinde düşünmeye sevk etmesi bakımından önemlidir. $\mathrm{Bu}$ yaklaşım, ekolojik değişimin varlığına ve ciddiyetine işaret etmekle birlikte bunu kapitalizm, güç ve sınıf çelişkilerini içeren tarihsel bir sorgulamayla ele almayı ön plana çıkarır. İnsandoğa, toplum-devlet gibi antagonizmalar üzerinden bir bakış geliştirmek yerine, ekolojik olana yaklaşırken doğa-insan, ekonomi-siyaset, devlet-toplum ilişkiselliğini göz önünde bulundurmaya teşvik eder. Bu bağlamda Kapitalosen kuramı, sosyal ve ekonomik sistem olarak algılanan kapitalizm anlamına gelmez. Kapitalosen kuram, Kapitalizmi doğayı organize etme biçimi olarak tanımlayan, tarihi de Sermaye Çağı’nda doğa, sermaye ve gücü içeren dünya ekolojisi [worldecology] olarak okuyan bir yaklaşımdır (Moore, 2016b, s.5-6). Bu yüzden, iktidar, üretim, yeniden üretimin oluşturduğu yaşamsal ağda sınırsız sermaye birikimine yol açan kapitalist sistemi anlamlandırmak için kullanılabilecek bir bakış açısı sunar. Ekoloji kavramına insan yaşamı yahut doğal yaşamın bir unsuru olarak değil üretim ilişkilerini de içine alan ve tarihsellikten beslenen bir okumayla yaklaşmayı hedefler (Patel ve Moore, 2017).

Ekoloji kavramı, bilimsel ve politik yaklaşımlarla ele alınabilmektedir. Ele aldıkları konular ve olgulara yaklaşımları yönünde farklılaşan bu iki bakış açısından ilki toprak ekosistemine bağlı olarak, diğer bir ifadeyle doğal kaynaklar temelli insan aktivitelerinin üretim ve yeniden üretim aşamalarına konu olan yapıyı ifade eder (Gorz, 1992, s. 58). Bu yaklaşım doğayı domine etmeyi ve rasyonel bir biçimde onu yönetmeyi gözetir. Politik olarak ele alınan ekoloji kavramının, diğer bir ifadeyle politik ekolojinin ise toplumun ve doğanın birbirinden ayrı olan iki unsur olarak görmediğini söyleyebilmek mümkündür. Çevre krizi yerine ekolojik kriz söylem tercihinde kendisini gösteren bu tutum, doğayla bağlantılı bir insanlık tahayyülü ortaya koymaktadır ki bu bakış tüm evreni ilişkisel olarak yorumlamayı gerektirir (Kovel, 2007, s.14).

Ekolojik olan ise, Moore’un (2015, s.15-16) Oikeios olarak nitelediği, yeryüzüne paydaş olanın ekolojisidir. Bu manada ekoloji, türlerin ve çevrenin yaratıcı, üretken ve çok-katmanlı ilişkiler dizgesini ifade eder. Türler çevreyi, çevre türleri yaratır. İnsan eylemleri ve örgütlenmeleri çevre yapıcı süreçlerin [environment-making process] neticesinde gelişir ve bu denklemde doğa ve insanlık birbirine içkin iki unsur olarak görülmelidir (Moore, 2016c, s.79). Çünkü Doğa ve toplumu ayrı iki varlık olarak görmek Doğa’yı tahakküm altına alıp ekonomik büyüme adına onu 
düzenleyip sayısallaştırma ve mantıksal hâle getirmenin bir uzantısıdır (Moore, 2015, s.205). Bu yüzden Kapitalosen kavramının sermaye ilişkileri vurgusuna ve kültürel anlamına temas etmek önem kazanmaktadır. Sermayenin üretim faaliyeti çevresel koşullara göre değiş̧tiği gibi çevreyi de beraberinde dönüştürür, bunun çevresel açıdan hesap edilmemiş yahut bilindik sonuçları olur; böyle bakıldığında doğal felaket denilen, kapitalist sistemin üretim ilişkilerinin hayatı tehdit edici boyutlardaki işleyişidir (Harvey, 2020, s.44). Covid-19 pandemisi ile tecrübe edilen bu işleyişin yansımasıdır. Bu durumda insanın doğa ile meselesi, doğa üzerinde kurduğu tahakkümünün sınırları değil; ekoloji, insan ve kapitalin karmaşık ilişkisinin sorgulanması olarak görülmelidir. Başka bir deyişle, bugünün problemi Kapitalosen’in sonunun gelmesidir (Moore, 2016c, s.113). Covid-19 pandemisi de Kapitalosen'in ekolojik bir sorununu teşkil etmektedir.

Liberal ekonomilerin piyasa sisteminde dışsallık atfedilen ve bu yolla hesaplanan doğaya bir dünyaekolojisi gözlüğünden bakmak insan ve doğayı birlikte düşünmek, dolayısıyla üretim ilişkilerine konu olan doğanın metalaştırılma düzeyini de sorgulamak anlamına gelmektedir. Bu tutum, yerkürede gerek zoonotik hastalık gerekse iklim krizi olarak meydana gelen ekolojik felaketleri farklı bir pencereden anlamlandırmayı olanaklı kılar. Kapitalizmin daima büyüme mantığındaki sahip olma ve faydalanma istemi sermayenin büyüme alanlarının doğada sınır tanımaması ile sonuçlanmaktadır. Kapitalizm doğal olanlardan faydalanır ve onları en ucuz haliyle nasıl işleyeceğinin yollarını arar (Patel ve Moore, 2017). Fakat bu arayışın doğal kaynakların kullanımı, toprağın aşırı ve yanlış işlenmesi, sudaki ve karasal yaşamdaki verimlilik esaslı üretimlerdeki ileri teknolojik uygulamalar, enerji kaynaklarının yıkıcı kullanımı, okyanus asitlenmesi gibi ekolojik felaketlere sebebiyet vererek yeryüzündeki metabolik dengeyi bozduğu anlaşılmaktadır (Başkaya, 2017, s.39-40). Öyle ki kapitalizmin daima büyüme mantı̆̆ının ardındaki rekabet ve birikime dayalı üretim ilişkilerinin yeryüzüne katkısı iklim krizi, okyanusların asitlenmesi, biyoçeşitlilikte azalma ve türlerin yok olması şeklinde olmuştur. Örneğin, WWF’nin 2020'de yayımlanan raporuna göre 1970-2016 ylları arasında vahşi yaşamdaki nüfusta \%68’e kadar azalma olduğu saptanmıştır (WWF, 2020, s.16). Okyanus asitlenme değerinde ise son iki yüz yılda 0.1 ünitede \%30 artış yaşanmıştır (Cooke ve Kim, 2018, s.67). Sermaye artı değer üzerinden kâr etmeyi amaçlayan bir ilişki olarak algılandığında, genişleyen değerler üzerinden sınırsız ve ihtiyaç temelli hareket edilmeyen bir yapı oluşturduğu görülür. Kâr maksimizasyonunu hedef alan bu mantıkta, insan emeği ve doğa da büyümeye konu olacak bir meta unsur olarak karşımıza çıkmaktadır (Magdoff ve Foster, 2011). Kapitalizm doğayı sömürmeden büyüme hedefine ulaşamaz, bu sebeple tıpkı pandemi döneminde olduğu gibi kriz zamanları gerçekleştirilen politikalar doğanın bozulan dengesini korumaya yönelik radikal çözümler üretmek için değil doğadan verim alabileceği ölçüde onu sürdürülebilir kılmak üzerinedir.

Öte yandan Covid-19 pandemisi ekolojik krizle ilişkilendirildiğinde metalaştırılmanın da bir sınırı olduğu görülmektedir. The FAO Global Forest Resources Assessment verilerine göre, biyoçeşitlilik ve habitatların tahribatı ile hayvansal hastalıkların insanlara taşınması arasında ilişki vardır. Ormanların tahribatı, insanların artan nüfusun ihtiyaçlarını karşılamaya yönelik doğal alanları işgal etmesi gibi sebeplerle insan ve yabani hayvan yakınlaşması, hastalıkların 
yayılmasında bir risk faktörü olarak karşımıza çıkmaktadır (Morand ve Lajaunie, 2020; UN E.P. ve ILRI, 2020, s.29).

Ekolojik krizin tekil boyutu gibi görünen, 2020 senesinde insanlığın yüzleştiği sorunların en şiddetlisi olarak göze çarpan Covid-19 gibi, orman yangınları ve çekirge istilası vb. ile örneklendirilebilecek (Malm, 2020) ekolojik krizin yansımaları olarak virüsün yayıldığı döneme eşlik eden diğer felaketler düşünüldüğünde, bu krizin yalnızca biyolojik etmenlerden doğmadığ1 söylenebilir. Bu bağlamda, virüsü bir suçlu olarak görmenin rahatlı̆̆ i içinde, dünyada olup bitenin ekolojik kriz gibi bir şokun özeti (Malm, 2016) ve bunun da kapitalizmle ilişkili olduğu gerçeği ihmal edilmektedir. Buna karşın devletlerin Covid-19 ile mücadele kapsamında ekolojik krizle ilişkilendirilerek geniş önlemler almadığı görülmektedir. Aksine, pandeminin bir sağlık krizi olduğu yönündeki yaklaşımlarla Covid-19 pandemisinin acil müdahale gerektirdiği vurgulanmış; fakat bu ekolojik krizle bağlantılı olarakgündeme taşınmamıştır. Kamusal uygulamalarla öne çıkan ülkelerden, Türkiye, pandeminin sağlık krizi olarak hızlı ve etkili önlemlerle kontrol edilmeye çalışıldığına işaret ederken, Fransa’da ise sağlık krizi olarak Covid-19'la mücadele kapsamında yeni yasal düzenlemeler hayata geçirilmiştir (Service Public Fr, 2021; TC Cumhurbaşkanlığı, 2021). Pandemi karşısında zorlayıcı ve önleyici tedbirlere başvuran devletlerin ekolojik kriz gündemlerine bu ağırlığı vermemeleri yönündeki tercihlerine dair çıkarım yapabilmek, Covid19'un kapitalist devletlerin varlığını doğrudan tehdit etmeyen; fakat ekolojik krizle ilişkili olarak ele alındığında radikal politik dönüşümlere sebep olabilecek yapısıyla açıklanabilir.

Virüs her ne kadar iklim değişikliğine sebep olan fosil yakıt kullanımı ve anti-ekolojik üretim biçimlerinin doğrudan bir sonucu olmasa da (Malm, 2020) üretim ilişkilerinden doğan tahribatla bağlantılıdır. Hayvanların sığınakları konumunda olan alanların şehirle birleşmesi, endüstriyel tarımın hastalıkların ortaya çıkışı ve yayılımını hızlandıracak şekilde gerçekleştirilmesi, özgür olmayan hayvanlar kümesi kurulması ve azalan biyoçeşitlilik sebebiyle türler arasındaki zoonotik hastalıkların ilk genotipleri mutasyon geçirmeden insan türüne ulaşabilmektedir. Ormanda yaşayan hayvanların taşılığı patojenlerin, sermayenin büyümesi adına yürütülen ormansızlaştırma ve kentleşme etkinlikleri ile tahrip edilmesi ile alt kümelerinin kaybedilmesi sonucu, zoonotik patojenlerin halk ve çevre sağllğını tehdit edici bir şekilde insan konağına taşınması söz konusudur (R. Wallace vd., 2020). Bugün, insan patojenlerinin yüzde 60’’nın vahşi hayvanlardan yerel insan topluluklarına doğru yayıldığını söylemek mümkündür (Foster ve Suwandi, 2020). 2000'li yıllardan itibaren yapılan araştırmalardan edinilen veriler ise insan hastalıklarının yüzde 70 'in üzerinde bir oranla hayvan kaynaklı olduğunu göstermektedir (Slingenbergh ve FAO, 2013). Virüsün Wuhan kentindeki yabani hayvan pazarından yayılarak tüm dünyayı etkisi altına aldığı kabul edilirse, doğa üzerindeki metalaştırma düzeyinin dolaylı yoldan da olsa insan türünün sorunu haline geldiği ortaya çıkmaktadır. Böyle bakıldığında, SARS, H5N1, Ebola gibi diğer zoonotik hastalıkları tecrübe etmiş devletler Covid-19 ile ekolojik kriz bağıntısını göz ardı ettiği noktada pandemiyi yalnızca sağlık krizi kapsamında ele alsa dahi Covid-19'un kendi başına alışılmadık ve tekil bir örnek oluşturmadığı söylenebilmektedir. 
Zoonotik patojenlerin yayılımı ve iklim krizi başta olmak üzere çevresel değişimler arasındaki ilişkiyi konu edinen birçok araştırma bu savı destekleyici niteliktedir. Sosyoekonomik ve çevresel etkilerden hareketle hayvancıllk faaliyetlerinin yürütülmesi, gıda sisteminin oluşturulması ve bu zincire yabani yaşamın da dahil edilmesi son dönemlerde zoonotik hastalık kaynaklı enfeksiyonların artışında etken olmuştur. Covid-19'u içine alan 2020 senesinde Kongo Demokratik Cumhuriyeti’nde ortaya çıkan Ebola, Nijeryảdaki Lassa Ateşi de ekolojik krizin yeryüzünün farklı birçok yerinde eşzamanlı krizlere yol açtı̆̆ını göstermektedir (Everard, Johnston, Santillo ve Staddon, 2020, s.1). Öte yandan, kapitalizmin metalaştırdığ 1 alanlarda kâr odaklı üretimin besin zincirinde oluşturduğu tahribatın biyoçeşitlilikte yarattığı azalma ile insanlarla hayvanların yaşamsal temasının artmasına ve bu yolla zoonotik patojenlerin ara türler arasındaki geçiş olmaksızın doğrudan insan türüyle karşılaşmasına sebep olmaktadır. Ekolojik sistemdeki biyoçeşitlilik azalmasıyla bağlantılı şekilde, yaşanan krizin neticesi olarak zoonotik rezervuarların çokluğunda bir artış meydana geldiği saptanmaktadır. İklim değişikliği, yaşam alanlarına müdahale ve aşırı hasat etkinliklerinin bu yıkıcı ilişkiye etkisi dikkate değer bir çalışma alanını oluşturmaktadır (Keesing ve Ostfeld, 2021, s.7). Ekosistemlerin bozulmuş yapısına ilişkin yürütülen çalışmalar, bu alandan üretilen hizmetlerin ve doğal kaynakların azalmasıyla sonuçlanan faaliyetlerin yürütüldüğü yönündedir. Özellikle sağlık açısından önem taşıyan alanların geleceği sorunu insan odaklı sağlık düşüncesine dayalı stratejilerin yetersiz temsili karşısında kilit bir faktör olarak kabul edilmeye başlanmıştır (Everard vd., 2020, s.11). Dolayısıyla ekosistemin sekteye uğraması birbirine zincirlenen birçok türün yaşamına mal olmakta, doğal dengedeki bozulma kıtlık, istila ya da salgın olarak ortaya çıkmaktadır. Olası pandemiler haritası çizildiğinde zoonotik temelli hastalıkların besin zincirindeki kırılma, sürdürülemez tarımsal faaliyetler, yaban hayatının sömürülmesi gibi başlıca antropojenik faaliyetlerden kaynaklandığı belirtilmektedir (UN E.P. ILRI, 2020). Bu tür toplumsal sağlik krizlerine sebep olan üretim ve tüketim biçimleri üzerinde yeniden düşünmenin, sorunu aşmada önemli bir adım olduğu görülmektedir. Bu sebeple odağa kapitalist sistemin ilişkiler zincirini alan Kapitalosen ve dünyaekolojisi vurgusu ekolojik, ekonomik ve siyasal unsurlar arasındaki bağlantıyı tanımlayabilmek adına geçerli bir bakış sunmaktadır. Bu çerçevede, Sermaye Çağı’nda tekil salgın hastalıklara devletlerce yerel ölçekte ve geçici olmak suretiyle alınan önlemlerin ekolojik krizin süregelecek yansımalarına çözüm üretmekte yetersiz kalacağı, birbirini izleyen pandemiler silsilesinde kapitalist sistemin rekabetçi ve büyüme odaklı ekonomik sistemi koruyarak devam edemeyeceği öne sürülebilmektedir.

İnsanın ekolojik varlığıyla bütünsel bir yaşam ağı oluşturan alanda bu ilişkilerin anahtarı olarak üretim koşulları göz önünde bulunduruluyorsa ekolojik kriz söz konusu olduğunda da bunun bağlantı noktasının aranacağı yer yine burasıdır (Kovel, 2007, s.15). Doğa dünya-ekolojisinin unsuru olarak ele alındığında, Covid-19 pandemisinin yalnız bir sağlık krizi değil, aynı zamanda ekolojiyle ilişkili bir kriz niteliğinde olduğu da söylenebilmektedir. Bu bağlamda devletlerin Covid-19 pandemisi için kapitalizmi karantinaya almak pahasına aldığı acil önlemlerin ekolojik kriz gündemi için oluşturulmaması bu iki unsur arasındaki ayrımın politik bir araç olarak 
devletlerce kullanılabilme kapasitesi ve kapitalizmin devamlılı̆̆ı sorunu ile açıklanabileceği fikrini ortaya çıkarmaktadır.

\section{Kapitalizmi "Karantinaya Almak"2}

Virüsle mücadelede dünya genelinde, pandeminin seyri ve vaka sayılarından hareketle ${ }^{3}$ başarılı bir politika yürütemedikleri bariz olan devletler, Andreas Malm’ın deyimi ile "kronik acil", Clark ve Foster'ın ise "gezegensel aciliyet” (Foster ve Clark, 2020) olarak adlandırdığı ekolojik krize karşı kesin ve hızlı önemler almakta çekingen davranmaktadır. Kapitalist üretim ve tüketim zincirinin yol açtığı karbon salımı, toprağın yanlış ve aşırı kullanımı ile paralel seyreden Covid19'un, yirmi birinci yüzyılda karşılaşılan en büyük felaket olsa dahi yayılımı hızlı ve etkisi şiddetli olan virüslerin son örneğini teşkil etmediği bir gerçektir (Malm, 2020). Bu durum, insanlığın savunmasız kaldığı apokaliptik gelecek senaryolarını giderek daha çok gündeme getirmektedir. Ekolojik krizin Covid-19 özelinde kendini hissettiren bu çarpıcı etkisine karşı devletlerin ajandasında pandemi sürecindeki gibi radikal kararlar yer almamaktadır. Trump’ın iklim değişikliğine inanmaması (Sangomla, 2020), Türkiye ve İran gibi önemli sera gazı salımı olan ülkelerde Paris Anlaşması'nın hayata geçirilmemesi (Eroğlu, 2020), krizin ekolojik boyutunun önemle dikkate alınmadığının birer göstergesi olarak yorumlama imkânını doğurmaktadır.

Pandemi kapitalizmin sebep olduğu ekolojik, epidemiyolojik ve iktisadi kırılganlıklar arasındaki bağlantıyı görünür kılmıştır (Foster ve Suwandi, 2020). Öyle ki pandemiyle mücadelede devletler salgının ortaya çıkardığı kriz ortamında kapitalizmin çıkmazlarını gözler önüne sermiş, kamusal hizmetleri özelleştiren ülkeler ve diğerleri arasında bu çıkmazların görünürlügü açısından dereceli bir farklılık yaşanmıştır (Gülalp, 2021, s.21). Bu durum, sistemin işleyişini ve etkisini doğrudan gözlemleyemediğimiz kapitalizmin krizinin ortaya çıkma sebebiyle ilişkilidir. Moore’un teorisinden yola çıkarak bu süreç, ekolojik krizin hissedilen etkilerini yansıtan, ucuz doğa stratejisinin bunalımı olan, sınırları artık aşılamayacak haldeki Kapitalosen’in son aşaması olarak da değerlendirilebilir. Ekonomik ve sosyal bir sistem bakışıyla kapitalizmi yaşamsal ağın hem üreticisi hem üretimi olarak düşündüğümüzde (Hartley, 2016, s.158), doğa ve insan diyalektiği bu sistemin sınırları içinde çeşitlenen ve yıkıcı etkileri bugün pandemi düzeyinde belirginleşen bir unsur olarak karşımıza çıkmaktadır. Dolayısıyla virüsün yayılımını engellemeye yönelik her hamlenin ekonomik, politik ve aynı zamanda ideolojik veçheleri vardır.

Ekolojik kriz ile epidemiyolojik krizler arasındaki bu ilişki, kapitalist üretim tarzının teşvik ettiği eylemlerin sonucu olarak okunabilir. Böylece her iki sorunun çözümüne dair formülü kapitalist sistemin politik ekonomisinde aramak gerekmektedir. Bugüne dek kapitalist devletler, üretim maliyetlerindeki artışın doğal sınırlarını, muhtelif ucuz doğa stratejileri yaratma, haritalama,

2 Andreas Malm, Corona, Climate, Chronic Emergency adlı kitabında Covid-19 karşısında kapitalist devletin durumunu "capitalism in quarantine" şeklinde nitelemektedir. Bu yazıda kullanılan ifadenin orijinal kullanımı kendisine aittir.

3 17/08/2021 itibariyle Dünya genelinde vaka sayısı 208.609.830’a ulaşmış, Covid-19 virüsü kaynaklı ölümlerin ise dört milyonun üzerinde olduğu tespit edilmiştir (CSSE, 2021). 
sayısallaştırma ile aşabilmiştir (Moore, 2016c, s.114). Pandemiyle görülen ise, küresel ölçekte büyük ekonomik ve sosyal krize yol açtığı bu haliyle kapitalizmin son eşiğe geldiğidir. Her ne kadar sonsuz büyümeyi hedefleyen yeşil kapitalizm olarak adlandırılan, kapitalist politikalara ekolojik dokunuşlar yaparak sistemin sürdürebilirliğini temiz üretimle sağlayan girişimler mevcut olsa da (Foster ve Clark, 2020) bu çabaların ekolojik krize çözüm arayışında olmadığı, sınırlı bir alanda ve yine maddi imkânların gerekliliğini dayatan bir düzen içinde eşitsizliği yeniden üreteceği söylenmelidir. Ekolojik krize çözüm arayışlarının yerini çevre dostu görünümle sektörlerin hayatta kalma çabaları almakta, bu çabalar kapital ağın korunmasına yönelik girişimlerle gerçekleştirilmektedir. Burkett’a göre bu tür ekonomik modellemeler çevresel etkilerin her toplum üyesi için aynı etkiyi yaratacağı hesabından yola çıkar. Bu tutum sermaye birikim mantığının göz ardı edildiğinin göstergesidir (Burkett, 2006, s.216-17). Dolayısıyla, daha yeşil bir dünya ekonomisi tasarımında yalnızca dışsal etkileri çözmeye yönelik modellemeler, pandemide olduğu gibi radikal kamusal kararlar almak yerine üretim ilişkilerinden doğan zenginlik ve güç dağılımını eşitsiz bir şekilde yeniden üretmektedir. Bu tutum, soruna kökten çözüm bulmak bir yana, ekolojik krizi sermaye lehine idare etmeyi hedeflemektedir. $\mathrm{Bu}$, kapitalizmin krizden faydalanma kabiliyeti doğrultusunda kendisini yenileme stratejilerinden yalnızca biridir. Kapitalist üretim ilişkilerine bağlı ulus devletlerde yaşanan krizler devletin ve sermayenin yeniden yapılandırılması için önemli işlev görürler (Yalman, 2021, s.100).

Pandemide ortaya çıkan durum, devletlerin bu yapısal krizden yönetim stratejileri geliştirilmesi yolu ile kısa vadeli çözüm üretebildikleridir. Covid-19 şekline bürünen ekolojik, ekonomik ve politik ilişki, kapitalist sistemin dayandığı eşik olarak, Sermaye Çağı’nda kapitalizmin yer yer karantinaya alındığı bir aşama olsa dahi kapitalist devletler bu krizi pandemi şartlarında kendi lehine işletebilmiştir. Bunun aksine, devletler büyük ölçekli bir planlamayı ve eşitlikçi ve adil bir yöne doğru sistem değişikliğini dayatan ekolojik krizi avantaja çevirebilecek mekanizmalardan yoksun kalmaktadır. Kapitalist devletlerin pandemi karşısında aldığı mücadeleci pozisyona karşın ekolojik krize görece daha minör tepkiler vererek mesafeli kalmasının sebebi, sistemsel bir dönüşümü dayatan pandeminin belirginleştirdiği bu gidişatın değişmesi yönündeki gerekliliği ile ilişkilendirilebilmektedir.

Pandemi sürecinde devletlerin politikalarına yansıyan, koşullarının zorunlu kıldığı, kolektif sorumluluktan pay almanın gündeme gelmesi, rasyonel bireylerden ve onların etkinlik alanı olarak görülen piyasadan müteşekkil bir sosyal gerçeklik yaratısı olan neoliberalizme ters bir izdüşüm yarattı̆̆ gözlemlenmektedir (Condon, 2020). Kapitalist devlet, sistemi karantina alma pahasına, sınıfsal doğasından ayrışı gibi görünerek geniş ve kapsayıcı birtakım politikalara yönelmiştir. Birçok ülkede yürütülen eve kapanma uygulamaları, okulların uzaktan eğitimle sürdürülme kararlarının verilmesi, fabrikalarda imalat faaliyetlerine ara verilmesi, restoranların kapatılması, eğlence sektörünün durdurulması (DW, 2020) şeklinde örneklendirilebilecek, piyasa ekonomisini sekteye uğratacak birçok politikanın virüsün yayılımını engellemek adına uygulamaya konulduğu görülmektedir. 
Malm’n (2020) normal politikalardan kaçınma vakti olarak yorumladığı bu süreç, devletin ve sermayenin alışılagelmiş eylem biçimlerinde değişiklik yapmak zorunda kaldığını göstermektedir. Pandeminin başında halk sağlığını korumaya yönelik sektörler gelişmeye başlamıştır. Kıyafet fabrikalarının maske üretimine geçtiği, parfüm firmalarının ve takıların yerini hayatı korumakla ilgili yeni ürünlerin aldığı (Malm, 2020) pandeminin ilk döneminin, üretim ve tüketim biçimlerini ihtiyaç mantığ 1 içinde gerçekleştirilmesi ile sınırsız üretim ve gereksiz tüketimi dayatan neoliberal mantığa ters düştügü görülmektedir. Her ne kadar bu durumda ekonomik tercihlere yönelik değişim sermayenin büyüme endeksli yaklaşımında kırılma olduğu yanılsamasını yaratsa da sektörün alan değiştirmesi kısa vadede sermayenin kâr oranlarının düşmesine sebep olmuş; uzun vadede ise toplumun zengin olan çok küçük bir bölümü için kârlı seyredecek bir ivme kazanılmıştır. Dünya Bankası’nın verilerine göre, pandemiden etkilenen zenginler bu süreçteki kayıplarını telafi etmekle kalmamış; servetlerini hızlı bir şekilde katlamış, buna mukabil aşırı yoksulluk dramatik bir biçimde artmıştır (BBC, 2020d; Neate, 2020; Read, 2020). Bu durumda, kapitalist sistem epidemik kriz ortamında kendisini yeniden üretecek zinciri kurmuş, kriz fırsata dönüştürülmüş̧ür. Öyleyse, aşı ve sosyal kısıtlama uygulamalarıyla zamanı öngörülemese dahi ekolojik kriz kadar uzun erimli politika sürdürmeyi gerektirmeyen pandemi, her ne kadar kamusal politikalar üretmekle mükellef olsa da bu durum kapitalist devleti uzun vadeli çıkarlarını tehdit eden bir unsur olarak görülmemektedir. Bu sebeple, ekolojik kriz için alınması gereken önlemlerin ve üretilmesi gereken çok yönlü politikaların - şimdilik - devletlerin kısa dönemli kâr ajandalarına uymadığı söylenebilir.

\section{Virüsle Savaşmanın Sınıfsal Veçhesi}

Pandemi, devletlerin kısa süreli hedeflerine uygun hareket manevralarının geliştirildiği bir sürecin önünü açmıştır. Bu süreç yalnız sermaye gruplarının ekonomik çıkarları lehine işlememiş, aynı zamanda devletlerin sürekliliklerini sağlamak ve toplumsal huzursuzluğu ortadan kaldırmak amacıyla araşsallaştırdıkları bir mefhuma da dönüşmüştür. Pandeminin gün yüzüne çıkardığg eşitsizliğin görünürlüğü, hastalıkta olduğu gibi ekolojik krizin de bu farklılıkları belirgin kılacağının bir göstergesi olabilmektedir. Kimin daha çok öldügü, kimin korunabildiği, kimin sağlık imkânlarından ne ölçüde faydalandı̆̆ı sınıfsal farklılıkları belirginleştirmiştir. Bu mücadeleden her kesimin aynı ölçüde etkilenmediği gerçeği pandemi ile derinleşen farklılıklar üzerinden kendini göstermektedir. Kimileri krizin etkilerinden kaçabilecekken, geri kalan çoğunluğun ise kötü şartlara mahkûm, korunmasız yaşadığı görülmektedir. Öyleyse kapitalist devletin pandemide koruduğu, refahını ve varlığını gözettiği sınıfların, ekolojik krizden en fazla etkilenecek ve zarar görecek kesim olmadığı sonucuna varılması olasıdır.

Pandeminin belirginleştirdiği sınıfsal farklılıkları görünmez kılmanın bir yöntemi olarak devletlerin savaş metaforu kullanmayı seçtikleri görülmektedir. "Savaştayız" (Lemarié ve Pietralunga, 2020) deklarasyonu ile genel seferberliğe çağrı yapan Macron'la Covid-19’a karşı devletlerin savaş açtığı söylemi ilk olarak siyaset sahnesine girmiştir. "Savaşzamanı hükümeti gibi hareket etmeliyiz” (BBC, 2020c); “Görünmez düşmana karşı savaş yürütüyoruz” (Sputnik, 2020); 
"Virüsle savaştayız, birbirimizle değil" (BBC, 2020a) gibi açılamalar bu söylemi takip etmiştir. Türkiye, Fransa, Birleşik Krallık ve Amerika Birleşik Devletleri hükümet söylemlerinde ortak olan unsur virüsün bir düşman, virüsle mücadelenin ise savaş konsepti kapsamında olduğunun vurgulanması olmuştur.

Savaş söylemi üreten devletlerin bu görünmez düşmana karşı yürütecekleri siyasette ölümü nasıl gerçekleştirecekleri değil de yaşamı nasıl ayakta tutacakları üzerinde düşünmek zorunda olmaları devletleri kapitalist repertuvarda bulunmayan halk sağlı̆̆ı, yaşamı koruma gibi toplumsal meseleler üzerinde karar almaya itmiş̧ir. Bu süreç neoliberal hükümetleri kendi sistemlerini sorgulama düzeyine çekebilecek bir test alanı yaratmıştır (Gambetti, 2020).

Kapitalist sistemin yapısından kaynaklı, ekolojik krizin tezahürü olarak meydana gelen Covid-19 virüsünün, sistemik ${ }^{4}$ niteliğini göz ardı edecek biçimde savaşa özgü bir terminoloji ile duyurulması bu yüzden tesadüfi değildir. Toplumsal iletişim ağları özellikle pandeminin gidişatı hakkındaki bilginin üretimi ve dağıtımı konusu devletin müdahale ettiği bir alan olarak karşımıza çıkmaktadır. Bu durumun Türkiye örneğinde olduğu gibi, istatistiki verilerin pandemiyle mücadelede başarının yegane göstereni olarak sunulmasının sembolik bir muharebe alanı oluşturduğu da söylenebilmektedir (Balta ve Özel, 2020). Devletin bu kapasitesinin tekil bir söylem olarak üç bileşeni vardır: (i) pandemiyi diğer hastalıklardan ayıran özelliklerin ve alınması gereken tedbirlerin kaçınılmazlığı vurgusu, (ii) herkesin dahil olacağı disiplinli bir hal içinde sorunun çözümlenebileceğinin öne sürülmesi, (iii) cephede savaşanlara minnettarlığın göstergesinin söylem yoluyla sunulması (Bouckaert, Galli, Kuhlmann, Reiter, ve Van Hecke, 2020, s.769-70). Verilerin tutulması, hastalık bilgilerinin istenilen düzeylerde aktarılması ya da örtülmesi, bu bilgi iktidarına sahip devletlerin pandemiyle mücadele için "dayanışmayı" hatırlamaları ve cephede savaşan, pandemiden ilk ve kaçınılmaz olarak etkilenmeye mahkûm edilen, çalışmak zorunda olan işçilerin ve pandemi özelinde hekimlerin tepkisini azaltmaya yönelik bir işlev gördüğü söylenebilir.

$\mathrm{Bu}$ retoriği milliyetçi söylemin yükselişi açısından ele alabilmek de mümkündür. Pandemi milliyetçi vurguların çoğalmasına, bunların etkin şekilde söylemde kullanılmasına olanak sağlamıştır. Ulusların diğer ulus devletler karşısında güçlü olma iddiası, rejimlerin var olan otoriterleşen eğilimlerini tetiklemiş, bu çizgideki politikaların uygulanmasına alan yaratmıştır. Olağanüstü şartların getirdiği zorunluluklar ve olanaklar, devlet gücünü harekete geçiren kurum ve aktörlere, diğer toplumsal ve siyasal özneler karşısında göreli bir karar alma ve uygulama kapasitesi kazandırmıştır. Alberto Toscano’nun (2021) belirttiği gibi virüse savaş söylemiyle yaklaşmak, tıpla askeriyenin tarihsel olarak birbirinden ayrılmasının güç olmasında yatan bilişsel mantığın, bir ideoloji aşamasının yahut uygulamanın bir yansıması olarak okunabilir. $\mathrm{Bu}$ sebeple sağlık alanında büyük bir krize yol açan ve kitlesel ölümlerle sonuçlanan Covid19’a karşı, hegemonyanın üreticisi olan devletin yürütme gücüyle, askeri bir vurguyla savaşta olunduğu söylemi arasında ilişki kurulabilmektedir. Benzer liberal süreklilik doğrultusunda sarf

$4 \quad$ Ekolojik ve kapitalist sistemin her ikisi de kastedilmektedir. 
edilen milliyetçi söylemlerin, devletin ve sermayenin girift küresel idaresinin üstünü örtme işlevi gördüğü söylenebilmektedir (R. Wallace vd., 2020).

Trump’ın koronavirüse yaklaşırken, hastalı̆̆ı genel kabulden farklı olarak pandeminin başlarında ısrarla "Çinli" yahut "Çin virüsü" olarak tanımlaması (BBC, 2020b), sermayenin sistemsel krizinde aradığı suçluyu, ötekileştirebileceği ve ekonomik olarak yarış içinde olduğu başka bir toplumda bulduğunu göstermektedir. Covid-19 pandemisinin ekolojik kriz ile bağlantısını ortadan kaldıracak şekilde sorunu jeopolitik bir düzlemde okumaya çalışmak bu krizin sistemin kendi meşruiyetini konsolide edecek milliyetçi söylemi tekrar üretmesinin yolunu açmaktadır (Condon, 2020). Ulus devlet hükümetlerinin siyasi varlığını tehlikeye düşüren, başarısız oldukları virüsle mücadele sürecinde toplumsal çelişkileri örtbas etmeye çalışma stratejisini milliyetçilikte buldukları söylenebilir. Burada bahsi geçen savaştaki tarafın virüs düşmanına karşı savaşan milletler olduğu lanse edilmektedir. Condon’n (2020) da belirttiği gibi, savaş zamanı hissiyle yoğrulmuş ortaklık gözeten "biz" unsuru bu süreçte insanlığın tamamını değil; farklılaşmış milletlerin kendi siyasal sınırları içindeki birliğine işaret etmektedir. Buradan hareketle, pandeminin yoksulluğu derinleştiren, zenginliği geliştiren yanının üzerini kapatacak bir örtünün savaş söylemine gizlenmiş milliyetçi kumaştan dokunduğu söylenebilir. Bu sebeple devletlerin, ekolojik krize karşı alınacak önlemlere nazaran pandemiye karşı görece farklı konumlanışının, pandeminin kapitalist devletlerin hedeflerini tehdit edici nitelik taşımasından kaynaklandığı iddia edilebilir. Çünkü ekolojik kriz "düşmanına" karşı yürütülecek savaş, tüm dünya uluslarının doğa-insan ilişkisel faaliyetlerinin ürünlerinin eşit ve adaletli biçimde paylaşıldığı, kriz karşısında birlikte mücadele edecek bileşik bir ortak kuvvetin varlı̆̆ını dayatmaktadır. O hâlde, ekolojik krizin, devletleri sınıfsal farklıkları ekarte ederek sürekliliğini sağlama yönünde üretebileceği milliyetçi bir söylemden faydalanma olanağından mahrum bıraktığı ileri sürülebilir.

Ekolojik krizle mücadelede takip edilmesi gereken, Malm’nn küresel ısınma karşıtı bir aktivistten aktardığı gibi, savaşın gerçek anlamda gezegensel mahiyetini vurgulayan biçimiyle Dünya Savaşı olma niteliğiyken, pandemi özelinde bu ekolojik savaşın da ulusal sınırlara indirgendiği görülmektedir (Malm, 2020). Ulusüstü örgütlerden AB’nin, pandeminin yayllım sürecinin başında İtalya’yı yalnız bırakması örneğinde görüldüğü gibi, pandemi üzerine gelişen milliyetçi söylemler, dünya genelinde yürütülmesi gereken dayanışma ve yardımlaşma ağlarını sekteye uğratma ihtimaline kapı aralamaktadır. Bir araştırma ekibinin Avrupalı devletlerin pandemi kriziyle mücadelede karar alma mekanizmalarını inceledikleri makalelerinde vardıkları sonuç bu çıkarımı destekler niteliktedir. Bu makale, krizle savaşımda her devletin farklılaşan bir eylem repertuvarı olduğunu tespit etmekle birlikte, ulusal çözümleri gerekli fakat yeterli olmadığ1 sonucuna varmıştır. Avrupa Birliği devletlerinin Avrupalılık mefhumu üzerinden dayanışarak pandemiye karşı savaş vermesi beklenirken, ülkelerin kendi sınırlarına çekilerek ulusal düzeyde soruna çözüm aramadıkları görülmüş, bu süreçte Avrupalı devletlerin tutumu koronamilliyetçiliği (coronationalism) olarak adlandırılmıştır (Bouckaert vd., 2020).

Pandemi devletine özgü bir şekilde yeni politikalar kapsamında değerlendirilebilecek, ayrışmaya dayalı bir mantıkla evlerde izolasyon, sosyal mesafe kuralları ve kimin evde kalıp virüsten 
korunabileceği sorunu, devletin yapısına dair sınıf çelişkilerini belirginleştiren bir sürecin izi olarak, Toscano’nun (2021) pandemi devleti tanımında kendisine yer bulmaktadır: "Modern devlet elindeki güç tekeliyle bir pandemi devletidir." Bu güç, devletin verileri denetleme, kontrol etme ve elinde bulundurma kapasitesiyle ilişkilendirilebilir. Toscano’nun "bir araya gelen" tehlikeli bireylere karşı "siyasal takıntının" salgın hükümetlerine özgü olduğu vurgusuyla işaret ettiği nokta bu bağlamda ilgi çekicidir. Burada siyasal takıntı olarak ifade edilen, gözetleme çağ kapitalizminde kontrol edilebilir ve denetlenebilir bireylerin salgın süresince bir araya gelerek hastalığı bulaştırma, suç yahut çatışma olgularına yol açan birlikteliklerine duyulan endişedir. Bu noktada devletin kamusal alanla beraber özel alanın düzenlenmesindeki rolü de göz önünde bulundurulmalıdır. Devletin baskı aygıtlarının dışında, toplumsal rızayı farklı mecralardan iktidar alanına dahil edecek, düzenleyici ideolojik kurumların varlı̆̆ı (Althusser, 1976, s.82-83) yalnızca yöneten sınıfın kendi fraksiyonlarını birleştirici güce değil, aynı zamanda sınıf çatışmalarını önleyici bir kabiliyete de sahiptir. İdeolojik aygıtlar, zor tekelinin kullanım biçimlerinin aksine, toplum nezdinde dayatmaya gerek kalmaksızın, kimi zaman sembolik kültürel ve teknik unsurlarca işlerler. Bu yönüyle bir politik kriz devletin hem baskı hem de ideolojik aygıtlarında cisimleşen, kaçınılmaz bir meşruiyet krizine işaret eder (Poulantzas, 2010, s.415).

Pandemi devletinin ise siyaseten özne olanın ${ }^{5}$ siyaset alanından dışlanması hatta gerçek anlamıyla evlerine hapsedilmesiyle, vaka sayılarının analizi ve sunulması, insan hayatına ilişkin istatistiksel verileri kapsayan ve manipüle edilmeye açı bir tür veriler hegemonyası altında yürütülmeye çalışılan girişimlerin meşruiyetini pandemi ile savaş söyleminde aradığ 1 iddia edilebilmektedir.

Dünya Savaşları̉na benzer seferberlik çağrılarıyla gerçekleşen virüse karşı savaşta aktif olan devletlerin, ekolojik krize karşı önlem almak konusunda seçici olmasının başka sebebi ise virüsün hangi kesime etki ettiği sorusunda aranabilir. Gelişmiş kapitalist devletlerin dışında kalan ülkelerin pandemiden en çok etkilenen ve yara alan kesimler olduğu söylenebilir. Pandemi örneğinde olduğu gibi, ekolojik krizin etkilerinin de en çok hissedileceği yerler bu mekânlardır. $\mathrm{Bu}$ noktada, Foster ve Suwandi’nin 21. yüzyıl emperyalizminin yapısına değinirken küresel sömürü sistemini tanımlamaları açıllayıcı olmaktadır. Bu sömürü sistemi, Küresel Güney’de üretilen artı değerin Küresel Kuzey'in kâr hanesine yazılmasına zemin hazırlaması ve yoksul ülkelerde üretilen değerin yerel düzeyin lehine kullanılmaması üzerine kuruludur (Foster ve Suwandi, 2020). Kapitalist üretim araçları ve kaynakların yerel alanın kontrolünden çıkarılıp küresel sermaye adına metalaştırılması ve kârının sermaye sahiplerine, Küresel Kuzey’e aktarılması söz konusudur. Küresel Güney’in mekânında üretim ilişkileri sebebiyle ortaya çıkan çevresel problemlerden etkilenenler uzun vadede yerel halk olmakla birlikte artı değeri elinde bulunduran hiçbir zaman bu kesim olmamaktadır. Dolayısıyla, bu eşitsiz ekonomik ve ekolojik değişimden en büyük hasarı Küresel Güney'in aldığı söylenebilmektedir (R. Wallace vd., 2020).

5 Siyaset devletin eyleme alanı içerisinde yer alan faaliyetlere indirgenemez. Burada "siyaset öznelerinin dışlanması” ile kastedilen, bir paydaş olarak siyasetin hem konusu hem öznesi olan yurttaşın siyasal olan ile toplumsalın ayrıldığı söylemine dayanak oluşturulacak şekilde yönetimsel alandan soyutlanmasının söz konusu edilmesidir. Bu bağlamda pandemi devleti politik karar mekanizmalarına dahil olamayan izole edilmiş yurttaş sorunu yaratmaktadır. [Le sujet politique] politik özne ya da politik olan manasında okunabilecek bu ifade için bkz. (Rancière, 1997) 
Buradan hareketle ekolojik krizin mağdurları olarak yine yoksul ülkelerin ve küresel sermayenin sömürdügü topraklardaki toplumların etkileneceği öne sürülebilir.

Wallace ve Wallace (2021) New York'ta Covid-19 etkilerinin 1rksal ve sinıfsal yönleri üzerine yaptıkları çalışmada, diğer hastalıklarda olduğu gibi bu virüsün Beyaz ve zengin olanlardan çok Siyah ve Latin insanları, yaşlıları, işçi sınıfını, düşük gelirli kesimleri etkilediğini ve virüsün bu kesimlerin ölüm oranlarını artırdığını ortaya koymaktadır. Bunun yanı sıra dikkat çeken diğer unsur ise Covid-19'un yaşlıları ve erkekleri daha çok etkiliyor olmasıdır. Bugüne dek karar mekanizmasının ajandasına dahil olmayan kamusal politikaların pandemi döneminde artırılması, etkilenen bu kesimin niteliğiyle ilişkili okuma fırsatı sunmaktadır.

Koronavirüs öncelikle yoksulları, işçi sınıfı etkilemesinin yanında devletin bugüne dek yalnızlaştırdığ ajandasında yer almıyorken pandemi sürecinde kendi olağan eylem dizgesinden çıkarak kapsayıcı politikalar ürettiğine tanık olunmuştur. Bu stratejik manevra, diğer hastalıklardan farklı olarak Covid-19'un herkeste aynı etkiyi yaratmaması (örneğin çocuklarda ve gençlerde ölüm riskinin az olması) ve özellikle yaşlılar ve erkekler için ölümcül olması (Mallapaty, 2020; O’Driscoll vd., 2020) gerçeğiyle ilişkilendirilebilir. Ulusal Sağlık İstatistik Merkezi’nin verilerine bakıldığında, ABD’de toplam nüfusa oranla erkeklerin yalnız Covid-19 kaynaklı ölümlerinin kadınlara göre daha fazla olduğunu kaydedilmiştir (National Center for Health Statistics, 2021). Bu sayısallaştırma girişimi her ne kadar hastane hizmetlerine ulaşım ve gelir seviyesi gibi politik-ekonomik parametreleri göz ardı ediyor olsa da virüsün cinsiyet düzeyinde dağılımını bir düzeyde ortaya koyması açısından ilgi çekicidir. Malm (2020), Koronavirüs'ün ekolojik krizden farklı olarak ortaya çıkan etkisinin bugünün insanını ve bilhassa Kuzey'deki yaşlı erkeği de tehdit etmesi olduğunu ileri sürmektedir. Bu hipotez, pandeminin aksine, ekolojik krizden etkilenen kesimi temel olarak küresel ısınma olgusu üzerinden geleceğe dair yapılan vurguyla gençler ve çocukların hedefte olması yönüyle farklılaştırmaktadır. Bir başka ifadeyle, Covid-19 ile mücadelenin bugünü koruduğu, ekolojik krizle yüzleşmenin ise uzak bir geleceği hesaba katmayı gerektirdiği savı öne çıkarılabilir görünmektedir. Foster ve Suwandi’nin Imperial College raporundan aktardığı bilgi de Malm’n bu çıkarımını desteklemektedir. Bu rapora göre gelir düzeyi yüksek ülkelerdeki 65 yaş üzeri yaşlı nüfusu yoksul ülkelere nazaran daha fazla olduğu için, ölüm oranlarının da zengin ülkelerde daha fazla olma riski vardır (Foster ve Suwandi, 2020; Walker vd., 2020). Öyleyse kapitalist devletleri repertuvarları dışına taşan kamusal politikalar yürütmeye teşvik eden koşulun pandemi karşısında yoksullar, işsizler ve gençler gibi kırılgan kesimleri koruma gereğinin yanı sıra belki daha büyük bir ağırlıkta, ekonomik olarak ayrıcalığa sahip mülk edinmiş kesimin de tehdit altında olmasıyla ilişkili olduğu söylenebilir. 


\section{Pandeminin Sunduğu İki Alternatif}

Sermayenin katmanlarının yer aldığı materyal ve doğal sınırları göz önünde bulundurarak Marx, sermaye değerlenmesinin olumsuz ve yıkıcı yönüne vurgu yapar (Foster ve Suwandi, 2020). ${ }^{6}$ İnsan-doğa ilişkisini ele alırken doğanın nesneleştirilmesini doğal bir ilişki süreciymiş gibi algılama yanılsaması içine düşülebilir. Halbuki burada nesneleştirilen doğa tıpkı insanlar gibi öznedir. İnsan emeğinin metalaştııılması gibi doğa da metalaştırılır. Kapitalist mantık doğanın bir nesne olarak sınırsız olduğu dayatmasından hareketle zihinlerde bu illüzyonu yaratır. Kapitalist üretim ilişkilerinin ekolojik boyutu göz önünde bulundurulduğunda, toprağın işletilmesi, küresel pazarlarda ürünlerin satılması ve neoliberal toplumun kullanım alışkanlıklarına göre şekillenen bu alım-satım fonksiyonunun yeryüzünde yarattığı tahribat kapitalizmin yıkıcı yanını ortaya koymaktadır. Doğal sınırlılık üzerinden gelişen üretim devrelerindeki yıkıcı ilişkiler bugün sermaye-pandemi-ekolojik kriz ilişkisini sorgulamayı zorunlu kılmıştır. Meta zincirinin bir parçası haline gelmiş doğal unsurların, olması gereken yerlerden koparılıp ticari alana taşınması vahşi hayvanlar ve insanlar arasında kaçınılmaz bir temasın gerçekleşmesi ile sonuçlanmıştır. Moore’un dünya-ekolojisi olarak nitelediği çerçeveden, Foster ve Suwandi’nin gezegensel yarık ${ }^{7}$ adıyla andığı üretim, doğa ve insan etkileşimindeki metabolik kırılmayı ortaya koyan Covid-19 ve türev hastalıklar Kapitalosen’in son eşiğinde olunduğuna işaret etmektedir.

Pandemiyle mücadelede ülkeler nezdinde virüsün bir savaşın tarafı olarak görülmesinin yanında, mücadelenin örtük yüzünün ekolojik kriz olduğu, hesaba katılması gereken unsurlardan biridir. Epidemik felaketler zincirini kuran, kapitalist üretim ilişkkilerinin yapısıdır. 2020 yılında pandemiyle edinilen tecrübe, sorumluluğu bir dünya-ekolojisi kavrayışı içinde algılamanın gerekli olduğunu ortaya çıkarmıştır. Yerkürede çeşitli yüzleriyle kendini gösteren, gündelik hayata temas etmediği için görünür olmayan ekolojik krizin hükümetlerin politik ajandalarına girmesi ertelenemez karakterinden dolayı öncelikli olmalıdır.

Kapitalist devletlerin, bilinçli bir şekilde koronavirüs dalgasına karşı genel, kapsayıcı ve toplumsal sınıf farklılıklarının üzerini örten bir söylem ile birlik çağrısı yaparak hareket edebildiği görülmüştür. Buna karşın, daha geniş bir perspektifte ekolojik krize karşı benzer bir politik tutum sergilenmediği söylenebilir. Her ne kadar hükümetler nezdinde ekolojik krizle mücadelede pazarlık konusu haline gelen karbon salımlarını düşürme hedefi gibi ortak proje ve anlaşmalar etrafında ekolojik krizin varlığını duyan ve kabul eden hareketlilikler olsa da pandemi karşısında alınan inkârcı tavırla mukayese edildiğinde ekolojik krizin aciliyetini görmeyen hükümetlerin sayısının fazla olduğu söylemek yanlıs olmayacaktır.

Devletlerin pandemi ve ekolojik kriz karşısındaki bu tercihli ve bilinçli davranışın sebeplerini şu şekilde sıralamak mümkündür: Devletler, ekolojik krizle bağlantılı olmasına rağmen Covid-19’u

6 Foster ve Suwandỉnin çıkarımsadığı nokta hakkında ayrıntılı bilgi için bkz. (Marx, 1993). Ekoloji ilişkisine dair Marksizme katkı sunan ve üç koldan Marx’ın eserlerinde ekoloji tespitini tartışan bir yazın için bkz. (Gunn, 2005).

7 Diğer bir deyişle, daha önce bahsedilen haliyle metabolik çatlak. Kovel, Foster’ın bu terim üzerinden Marx’ı okuyarak ekososyalizm ve Marksizm ilişkisini insan ve doğa arasındaki metabolik çatlak metaforu ile kurduğunu söylemektedir. Bu eleştiri hakkında daha fazlası için bkz (Kovel, 2007: 232). 
ekolojik krizden ayrı bir sağlık krizi olarak değerlendirmenin avantajıyla kısa süreli kontrol politikalarıyla önlem alabilmişler, bu krizden faydalanabilmişlerdir. Bunun yanı sıra ekolojik krizin aşamalı seyretmemesi ve uzun erimli olması sebebiyle ertelenebilir olduğu düşünülmektedir. Ayrıca, virüse karşı verilecek mücadele bugünün insanını korumayı amaçlarken, ekolojik krizin etkileriyle mücadele ise geleceğe ilişkin yapılandırma gerektiren politikaların hedeflenmesi anlamına gelmektedir. $\mathrm{Bu}$ sebeple, yerel düzeye çekilmiş mücadelede Koronavirüse karşı verilen tepkinin savaş kapsamında ele alınarak devletlerin toplumsal tansiyonu kontrol altına alabildikleri görülmüştür. Diğer yandan, pandemi ile mücadelede kullanılan savaş terminolojisi modern kapitalist ulus devletin meşruiyetini milliyetçilik ideolojisi üzerinden konsolide etme ve pandeminin sınıfsal farklılıklara tuttuğu ışığı söndürme çabasına katkı sağlayacak biçimde araçsallaştırılabilme imkânı sunmuştur.

Öte yandan, pandemide alınan kısa vadeli tedbirlerin aksine, ekolojik kriz ile mücadele etmenin uzun erimli kesin yöntemleri vardır. İklim krizine sebep olanın ve asıl düşmanın fosil kapitalizm olduğunu ileri süren Malm bugünün eylemlerinin gerçek ve görülebilir sonuçları olduğunun hissedildiğini ve bu sebeplerin değil eylemlerin dağılımının ve tercihinin yol açtığı etkileri pandemi süreci ile deneyimlediğimizi belirtirken (Malm, 2020), Koranavirüsün ekolojik krizde olduğu gibi sistemsel krizden kaynaklı yapısını vurgulamaktadır. Covid-19'u ekolojik kriz olarak görüp buna karşı doğrudan cephe almak, devletler nezdinde kapitalizme karşı savaş açmayı gerektirmektedir. Sweezy’nin deyimi ile, bu krizle mücadele için sistemin sebep olduğu hasarları yavaşlatmak değil, durumu ters yüz etmek gerekmektedir; bu bir ekonomik rejim değişikliği meselesidir (Sweezy, 2004).

Ekolojik kriz politik ekonominin temel problemi olarak karşımızda durmaktadır. İklim değişikliği gibi konularda belirgin girişimlerde bulunulsa da bu yeryüzünü korumaktan uzak bir yaklaşım olarak kalacaktır; zira kapitalizmin uzun vadeli projesi olan sürekli ve hızla büyüme gerekliliği söz konusudur (Foster, Clark, ve York, 2008). Bu durum, ekolojik krizin kaynağ 1 olan metalaştırma mefhumunu ortadan kaldırmayacaktır. Kısa sürede avantaja çevrilebilecek müdahaleler ile sermayeyi koruma ve dönüştürme, salgını yerel düzeyde çözse dahi sayısı artarak çoğalan ekolojik krizin diğer yansımalarına karşı yalnız sermaye sınıfının hayatını koruyan değil, gezegenin tüm bileşenlerini gözetecek şekilde gögüs gerebilecek bir sistem tasarısı kapitalizmin içinden devşirilememektedir. Ekolojik soruna karşı devletlerin kesin çözüm aramaması kapitalist neoliberal ekonomik sistemde birtakım ihlalleri göze alarak pandemiyi idare etme yoluyla devletlerin ve kapitalist sistemin sürekliliğini korumayı tercih ettiğini göstermektedir. Pandemi krizi ile mücadele de bu boyutuyla kapitalist devletin işlevsel olarak kullanabileceği bir firsat anına dönüştürülmüştür.

Ekolojik krizin diğer yansımalarıyla kısa vadede yüzleşecek Dünya, Covid-19 virüsü ile neoliberal pratiklerini test etmiştir (Condon, 2020). Koronavirüs'ün 2021 Ağustos ayı itibariyle mutasyonlu versiyonları ile mücadele edildiği düşünüldüğünde bu yüzleşme anının gerçekten de yakın olduğu söylenebilmektedir. Bu sebeple pandeminin iki alternatif politik tutumun yolunu açtığı iddia edilebilir. Birincisi, pandemi süresince tecrübe edilen politik-ekonomik manevraların kapitalizme 
yeni bir forma bürünmeyi dayatmasıdır. Yeşil kapitalizm adıyla, başta iklim değişikliği olmak üzere diğer ekolojik sorunlara duyarlı gözükürken eşitsizliği perçinleyen ve sistemin sürekliliğini sağlama amacıyla yapılanmaya gidilmesi bu birinci alternatifin alametifarikasıdır. İkinci seçenek ise derinleşen yoksulluğu, sınıfsal farklılıkları ve dayanışmaya duyulan gereksinimi daha açı bir şekilde ortaya koyan pandemi sürecindeki kolektif deneyimlerden hareketle, bu virüsü ve diğer olası varyasyonları ekolojik krizin bir boyutu olarak kabul edip her siyasal öznenin sorumluluk alarak, doğa-insan-üretim ilişkileri ağının oluşturduğu dünya-ekolojisinde mücadele ettiği bir zemin oluşturmaktır. Bu zemin ekolojik krizin etkilerini ortadan kaldıracak, adil ve toplumsal eşitliği esas alan bir ekolojik politik sistem hedefiyle inşa edilmelidir. O halde, her siyasal öznenin bir yerden dünyadaki bu dengesizliği onarmaya çalışması gerektiğine bir şerh düşerek katılmak mümkündür: herkesin dünyanın geleceği için mücadele etmesinin yanı sıra üretim ilişkilerindeki sömürü ortadan kaldırılmalı ve kaynakların, değerin adil dağılımı ilkesiyle örgütlenen dayanışma ağları kurulmalıdır.

\section{Kaynakça}

Almond, R. E. A., Grooten, M., ve Petersen, T. (2020). Living Planet Report 2020-Bending the Curve of Biodiversity Loss. Gland, Switzerland: WWF.

Althusser, L. (1976). Positions (1964-1975). Paris: Editions Sociales.

Balta, E., ve Özel, S. (2020). La bataille des chiffres : un faible taux de mortalité en Turquie. Retrieved April 9, 2020, from Institut Montaigne website: https://www.institutmontaigne.org/blog/la-bataille-deschiffres-un-faible-taux-de-mortalite-en-turquie

Başkaya, F. (2017). Başka Bir Uygarlık İ̧̧in Manifesto Nasıl Üretmeli Nasıl Tüketmeli Nasıl Yaşamalı. İstanbul: Yordam.

BBC. (2020a). Biden Thanksgiving speech: We're at war with the virus, not each other. Retrieved February 2, 2021, from https://www.bbc.com/news/election-us-2020.550.78066

BBC. (2020b). Coronavirus: Trump grilled on use of term "Chinese virus." Retrieved February 2, 2021, from https://www.bbc.com/news/av/world-us-canada-51953315

BBC. (2020c). Coronavirus: "We must act like any wartime government." Retrieved February 2, 2021, from bbc.com/news/av/uk-51936760

BBC. (2020d). Extreme poverty set for first rise since 1998, World Bank warns. Retrieved February 2, 2021, from https://www.bbc.com/news/business-54448589

Bennett, M. (1999). Zoonoses. Journal of Epidemiology \& Community Health, 53, 514-515.

Bouckaert, G., Galli, D., Kuhlmann, S., Reiter, R., ve Van Hecke, S. (2020). European Coronationalism? A Hot Spot Governing a Pandemic Crisis. Public Administration Review, 80(5), 765-773.

Burkett, P. (2006). Marxism and Ecological Economics Toward a Red and Green Political Economy. Leiden: Brill. https://doi.org/10.1163/978.904.7408567

Center for Systems Science and Engineering. (2021). COVID-19 Dashboard. Retrieved April 11, 2021, from Johns Hopkins University website: https://coronavirus.jhu.edu/map.html

Condon, R. (2020). The coronavirus crisis and the legitimation crisis of neoliberalism. European Societies 23(özel sayı 1), S805-S816. https://doi.org/10.1080/14616.696.2020.1839669 
Cooke, S. L., ve Kim, S. C. (2018). Exploring the "Evil Twin of Global Warming": Public Understanding of Ocean Acidification in the United States. Science Communication, 41(1), 66-89. doi: 10.1177/107.554.7018821434

DW. (2020). Koronavirüs ile mücadelede ülkeler hangi önlemleri aldı? Retrieved February 2, 2021, from Deutsche Welle Tr website: https://p.dw.com/p/3ZanU

Eroğlu, D. (2020). Türkiye’nin iklim eylemsizliği: 30 ylllık cendere. Retrieved February 2, 2021, from Teyit. org website: https://teyit.org/turkiyenin-iklim-eylemsizligi-30-yillik-cendere.

Everard, M., Johnston, P., Santillo, D., ve Staddon, C. (2020). The role of ecosystems in

mitigation and management of Covid-19 and other zoonoses. Environmental Science \& Policy, 111, 7-17. doi: 10.1016/j.envsci.2020.05.017

FAO. (2020). The COVID-19 challenge: Zoonotic diseases and wildlife. Collaborative Partnership on Sustainable Wildlife Management's four guiding principles to reduce risk from zoonotic diseases and build more collaborative approaches in human health and wildlife manag. Roma. https://doi. org/10.4060/cb1163en

Foster, J. B. (2020). Mutlak Kapitalizm. Monthly Review Türkçe, 9, 11-29.

Foster, J. B., ve Clark, B. (2020). Capitalism and the Ecological Rift The Robbery of Nature. New York: Monthly Review Press [Epub Formatlı Kitap].

Foster, J. B., Clark, B., ve York, R. (2008). Ecology: The moment of truth - An introduction. Monthly Review, 60(3). https://doi.org/10.14452/MR-060-03-2008-07_1

Foster, J. B., ve Suwandi, I. (2020). COVID-19 and catastrophe capitalism commodity chains and ecologicalepidemiological-economic crises. Monthly Review, 72(2), 1-20. https://doi.org/10.14452/MR-07202-2020-06_1

Gambetti, Z. (2020, Mayıs 19). Politics of Life vs. Politics of Death. Retrieved August 04, 2021, from Critical Times website: https://ctjournal.org/2020/05/19/politics-of-life-vs-politics-of-death/.

Gorz, A. (1992). Lécologie politique entre expertocratie et autolimitation. Actuel Marx, 2(12), 15-29. https:// doi.org/10.3917/amx.012.0015

Gunn, C. (2005). Book Review: The Enemy of Nature: The End of Capitalism or the End of the World? Review of Radical Political Economics 37(3), 405-7. https://doi.org/10.1177/048.661.3405279134

Gülalp, H. (2021). Kara Ölüm’den Covid-19’a, Kapitalizmin Yükselişi ve Çöküşü. Praksis, (55), 9-44.

Hartley, D. (2016). Anthropocene, Capitalocene, and the Problem of Culture. In J. W. Moore (Ed.), Anthropocene or Capitalocene? Nature, History, and the Crisis of Capitalism (pp. 154-165). Kairos.

Harvey, D. (2020). Covid-19 Günlerinde Anti-Kapitalist Siyaset. In E. Ünal (Ed.), Çivisi Çıkan Dünya Covid-19 Salgını Üzerine Muhasebeler (pp. 42-52). İstanbul: Runik Yayınları. Keesing, F., ve Ostfeld, R. S. (2021). Impacts of biodiversity and biodiversity loss on zoonotic diseases. Proceedings of the National Academy of Sciences, 118(17). doi: 10.1073/pnas.202.354.0118

Kovel, J. (2007). The Enemy of Nature: The End of Capitalism or the End of the World? (1st ed.). Black Point: Zed Books. https://doi.org/10.5040/978.135.0251007

Kuhn, T., ve Constantine, D. (2018). The Collected Poems of Bertolt Brecht. Liveright Publishing Corporation [Epub Formatlı Kitap].

Lemarié, A., ve Pietralunga, C. (2020). « Nous sommes en guerre » face au coronavirus, Emmanuel Macron sonne la «mobilisation générale». Retrieved February 20, 2021, from Le Monde website: https:// www.lemonde.fr/politique/article/2020/03/17/nous-sommes-en-guerre-face-au-coronavirusemmanuel-macron-sonne-la-mobilisation-generale_6033338_823448.html 
Magdoff, F., ve Foster, J. B. (2011). What every environmentalist needs to know about capitalism: A citizen's guide to capitalism and the environment. New York: Monthly Review Press. [Epub Formatl Kitap].

Mallapaty, S. (2020). The coronavirus is most deadly if you are older and male. Retrieved February 2, 2021, from Nature website: https://www.nature.com/articles/d41586.020.02483-2

Malm, A. (2016). Fossil Capital: The rise of steam power and the roots of global warming. Londra: Verso [Epub Formatlı Kitap].

Malm, A. (2020). Corona, Climate, Chronic Emergency: War Communism in the twenty-first century. Londra: Verso [Epub Formatl Kitap].

Marx, K. (1993). Le Capital: Critique de léconomie politique, cilt 1. Paris: PUF.

Marx, K. (2015). 1844 El Yazmaları: Ekonomi Politik ve Felsefe. Ankara: Sol Yayınları.

Moore, J. W. (2015). Capitalism in the Web of Life Ecology and the accumulation of capital. Londra: Verso.

Moore, J. W., der. (2016a). Anthropocene, Capitalocene, and the Problem of Culture. Kairos.

Moore, J. W. (2016b). The Rise of Cheap Nature. In J. W. Moore (Ed.), Anthropocene or Capitalocene? Nature, History, and the Crisis of Capitalism (pp. 78-116). Kairos.

Morand, S., ve Lajaunie, C. (2020). Outbreaks of Vector-Borne and Zoonotic Diseases Are Associated With Changes in Forest Cover and Oil Palm Expansion at Global Scale. SSRN Electronic Journal. https:// doi.org/10.2139/ssrn.3710299

National Center for Health Statistics. (2021). Deaths involving coronavirus disease 2019 (COVID-19), pneumonia, and influenza reported to NCHS by sex and age group, United States, (1/1/2020-2/13/2021). Retrieved from https://www.cdc.gov/nchs/nvss/vsrr/covid_weekly/index.htm\#SexAndAge

Neate, R. (2020). Billionaires' wealth rises to $\$ 10.2$ trillion amid Covid crisis. Retrieved February 2, 2021, from The Guardian website: https://www.theguardian.com/business/2020/oct/07/covid-19-crisisboosts-the-fortunes-of-worlds-billionaires

O’Driscoll, M., Santos, G. R. Dos, Wang, L., Cummings, D. A. T., Azman, A. S., Paireau, J., ... Salje, H. (2020). Age-specific mortality and immunity patterns of SARS-CoV-2 infection in 45 countries. MedRxiv, 2020.08.24.20180851. https://doi.org/10.1101/2020.08.24.20180851

Patel, R., ve Moore, J. W. (2017). A History of the World in Seven Cheap Things: A Guide to Capitalism, Nature, and the Future of the Planet. Black Inc [Epub Formatl Kitap].

Poulantzas, N. (2010). Poulantzas Kitabı Seçme Yazılar (J. Martin, Ed.). Ankara: Dipnot.

Rancière, J. (1997). Onze thèses sur la politique. Filozofski Vestnik, 18(2), 91-106.

Read, S. (2020). Billionaires see fortunes rise by $27 \%$ during the pandemic. Retrieved February 2, 2021, from BBC website: https://www.bbc.com/news/business-54446285

Readfearn, G. (2020). How did coronavirus start and where did it come from? Was it really Wuhan's animal market? Retrieved February 2, 2021, from The Guardian website: https://www.theguardian.com/ world/2020/apr/28/how-did-the-coronavirus-start-where-did-it-come-from-how-did-it-spreadhumans-was-it-really-bats-pangolins-wuhan-animal-market

Sangomla, A. (2020). US Elections 2020 A history of Trump's climate change denial. Retrieved February 2, 2021, from Down to earth website: https://www.downtoearth.org.in/news/climate-change/uselections-2020-a-history-of-trump-s-climate-change-denial-74075

Service Public Français. (2021). Le passe sanitaire devient européen à partir du 1er juillet. Retrieved August 05, 2021, from Service Public Français website: https://www.service-public.fr/particuliers/ actualites/A15022.

Slingenbergh, J., ve FAO (Ed.). (2013). World livestock 2013: Changing disease landscapes. Rome: FAO. 
Sputnik. (2020). Erdoğan: Görünmez düşmana karşı zor bir savaş yürütüyoruz. Retrieved February 2, 2021, from https://tr.sputniknews.com/turkiye/202.004.101041796719-erdogan-gorunmez-dusmanakarsi-zor-bir-savas-yurutuyoruz/

Sweezy, P. M. (2004). Capitalism and the environment. Monthly Review, 56(4). https://doi.org/10.14452/ MR-056-05-2004-09_6

TC Cumhurbaşkanlığı. (2021). “Türkiye, son bir asrın en büyük sağlık krizi diye nitelenen salgını, dünyada en başarılı şekilde yöneten ülkelerden biri olmuştur”. Retrieved August 05, 2021, from TCCB website: https://www.tccb.gov.tr/haberler/410/128579/-turkiye-son-bir-asrin-en-buyuk-saglikkrizi-diye-nitelenen-salgini-dunyada-en-basarili-sekilde-yoneten-ulkelerden-biri-olmustur-

Toscano, A. (2021). The state of the pandemic. Historical Materialism, 28(4), 3-23. https://doi. org/10.1163/1569206X-12342804

United Nations Environment Programme International Livestock Research Institute (Ed.). (2020). Preventing the Next Pandemic. Zoonotic diseases and how to break the chain of transmission. Nairobi. Retrieved from https://www.un.org/Depts/Cartographic/

Walker, P. G. T., Whittaker, C., Watson, O. J., Baguelin, M., Winskill, P., Hamlet, A., ... Ghani, A. C. (2020). The impact of COVID-19 and strategies for mitigation and suppression in low - And middleincome countries. In Science (Vol. 369). London. https://doi.org/10.1126/science.abc0035

Wallace, D., ve Wallace, R. (2021). COVID-19 in New York City An Ecology of Race and Class Oppression. Springer. https://doi.org/https://doi.org/10.1007/978-3-030-59624-8 [Epub Formatlı Kitap]

Wallace, R., Liebman, A., Chaves, L. F., ve Wallace, R. (2020). COVID-19 and Circuits of Capital. Monthly Review. https://doi.org/10.14452/mr-072-01-2020-05_1

Yalman, G. L. (2021). Kapitalizmin Krizleri Üzerine Gözlemler. Praksis, (55), 99-108. 


\title{
Why Don't the Pandemic-Fighting Capitalist States Fight Ecological Crisis in the Same Way? A Political-Ecological Approach to the Pandemic
}

\begin{abstract}
Aybala ERTEKIN ${ }^{*}$
The Covid-19 pandemic, which has not been contained for more than a year, has become the biggest political, economic, and social issue of the twenty-first century. During the pandemic, capitalist states had to implement policies penetrating every component of the society. There have been many efforts to take measures against the virus such as lockdown, closing restaurants, etc. When we consider the pandemic as a facet ecological crisis, this differing attitude of the states vis-à-vis those related crises is remarkable. Thus, it is puzzling that states have not fought the ecological crisis as they fought the pandemic. The purpose of this study is to ask the question why the preferences of states differ in the two situations.

To answer this question, it is necessary to reveal the nature of the coronavirus, its connection to the ecological crisis, and its relationship with the capitalist system. Hence, the problem leads us to the following arguments: A pandemic is an ecological crisis. The capitalist state does not respond to the ecological crisis, in the same way, it fights the pandemic. Due to the pandemic, while maintaining the continuity of the nation-state with a nationalist discourse, social class distinctions were covered up. But nationalist discourse does not seem useful to be utilized as an instrument in combating the ecological crisis. The ecological crisis requires a greater challenge to capitalism.

The crisis has arisen from the contact of humans with wild animals. The coronavirus is a zoonotic disease $(F A O, 2020)$ that cannot be considered independent from relations of production. As an element of nature, it is probable to encounter wild animals due to human production activities. The coronavirus originated in Wuhan. This area is a large marketplace where industrial production is promoted while generating capital as a commercial hub (R. Wallace, Liebman, Chaves, and Wallace, 2020). The fact showed us that the limits of nature, exploited by capitalist relations, have been reached. Thus, it is possible to examine both the pandemic-ecological crisis and relations of production through the Capitalocene theory. Capitalocene is an approach that
\end{abstract}

* Galatasaray University, E-mail: aybalaertekin@gmail.com, Orcid: 0000-0001-9822-7307. 
defines capitalism as a form of organizing nature and, reads history as world ecology that includes nature, capital, and power in the Capital Age (Moore, 2016b: 5-6). It differs from the concept of scientific ecology (Gorz, 1992), which expresses the structure that is subject to the production and reproduction stages of human activities based on natural resources. Political ecology is not considered as that these elements are separate from each other. The discourse of ecological crisis instead of environmental crisis also differs in this sense. When the ecological crisis is mentioned, the holism of humanity connected with nature is stressed. This view requires interpreting the whole universe as relational (Kovel, 2007: p.14). The ecological is the ecology of the stakeholder to the earth (Moore, 2015: p.15-16). The pandemic reflects one face of the human-nature-capitalproduction ecology. Like Covid-19, which is likely a singular dimension of the ecological crisis and stands out as the most severe of the problems faced by humanity in 2020, there have been many incidents that can be exemplified by forest fires and deforestation, etc. (Malm, 2020). With the deforestation and urbanization activities carried out by capitalists, zoonotic pathogens are transported to the human host in a way that threatens public and environmental health (R. Wallace et al., 2020). Considering these disasters accompanying the period in which the virus spread as the elements of the ecological crisis, it can be said that the pandemic is caused by the capitalist system. If the production conditions are taken into consideration as the key to the relationship with the human being himself and his environment, that is where the connection point of the ecological crisis must be sought (Kovel, 2007: p.15). This relationship between the ecological crisis and epidemiological crises can be accepted as the result of practices promoted by the capitalist mode of production.

On the other hand, states have created the concept of combating pandemics by using nationalist discourse to cover up the class struggle. Approaching the virus with the discourse of war can be read as a reflection of the cognitive logic, an ideology stage or practice, which lies in the historical separation of medicine and military from each other (Toscano, 2021). For this reason, a relationship can be established between the executive power of the state, which is the producer of hegemony, and the discourse of war with a military emphasis against Covid-19. Nationalist discourses function to cover up the global ruling of the state and capital (R. Wallace et al., 2020). Hence, the side of the pandemic that deepens poverty and improves wealth has been covered with nationalist discourse. For this reason, it can be argued that the comparatively different positioning of the states against the pandemic compared to the measures to be taken against the ecological crisis is due to the fact that the pandemic endangers the aims of the capitalist nationstates. As seen in the example of the European Union, European countries sought a solution to the problem at the national level. In this process, the attitude of European states has been named coronationalism (Bouckaert et al., 2020).

Based on all these, the article concludes as follows: The coronavirus crisis is not only a health crisis, but also an ecological one. The ecological crisis does not progress gradually like the spread of coronavirus. The fight against coronavirus is considered as a war, and it has found a place in the short-term state agenda more importantly and primarily compared to the measures to be taken against ecological crisis such as climate crisis and global warming. The war terminology 
used by capitalist states during the pandemic process provides the legitimacy of the modern capitalist nation-state through the ideology of nationalism. 